\title{
An Empirical Analysis of Agricultural Exports on Economic Growth in India
}

\author{
Murugesan, B.
}

Department of Economics, The Gandhigram Rural Institute, Gandhigram, Dindigul, Tamil Nadu, India

Corresponding author: ecomurugesan@gmail.com (ORCID ID: 0000-0001-9830-9214)

Received: 02-04-2019 Revised: 07-07-2019_Accepted: 19-08-2019

\begin{abstract}
This study has focused to analyze the influence of agricultural trade on economic growth in India obtaining annual time series data from 1990-91 to 2016-17. This study estimates the relationship between agricultural exports and economic growth in India employing the Error Correction Model. This study has used three variables such as, Gross Domestic Product (GDP), agricultural exports and non-agricultural exports. According to empirical estimates, the Error Correction Model, that is to say catch can tend towards the long run relationship, has been validated. The variables are converging to equilibrium value and the change in agricultural exports and non-agricultural exports are directly affecting the real GDP in India. Furthermore, this study found that there is short-run uni-directional causality between agriculture exports, non-agriculture exports to GDP in India. The main finding of this study is that the agricultural exports and non-agricultural exports are important variables to stimulate economic growth in India. This study recommends an increase effort to be directed towards policies that will expand the volume of a country's agricultural productivity and trade for the economic growth in the country.

Highlights

(0 This study identified that the agricultural exports stimulate economic growth in India. This study recommends an increase effort to be directed towards policies that will expand the volume of agricultural productivity and trade for the economy.
\end{abstract}

Keywords: GDP, Agricultural exports, Unit Root Test, Co-integration test and ECM

The most important and crucial aim of the developing countries is rapid economic growth and development and exports are generally perceived as an engine for economic growth. The desire for rapid economic growth in developing countries is attained through more trade. There is no shortage of empirical and theoretical studies regarding the role of exports in raising the economic growth and development. The classical economists like Adam Smith and David Ricardo have argued that international trade is main source of economic growth and more economic gain is attained from specialization. According to the export led growth hypothesis, exports are the major source of economic growth, has many theoretical justifications. First, in Keynesian theory more exports generate more income growth through foreign exchange multiplier in the short run. Second, Export raises more foreign exchange which is used to purchase manufactured goods, capital goods and technology. These things contribute to economic growth. Third, exports indirectly promote growth via increased competition, economies of scale, technological development, and increased capacity utilization. Fourth, many positive externalities like more efficient management or reduction of organizational inefficiencies, better production techniques, positive learning from foreign rivals and technical expertise about product design are accrued due to more exports, lead to economic growth. After reform, the agricultural exports, which was ₹ 6012.76 crore in 1990-91, has increased to ₹ 226651.94 crore in $2016-17$, that is, by 37.69 
AESRA

times. The agricultural imports, which was ₹ 1205.86 crore in 1990-91, has increased to ₹ 164726.83 crore in 2016-17, that is, by 136.60 times. However, the agricultural exports and imports has not maintained a uniform increasing trend but was marked by considerable fluctuations. The percentage shares of agricultural exports are continuously decreasing in total exports. The main aim of the present research is to examine the contribution of agricultural trade to economic growth in India.

In recent years, there has been an increasing amount of literature on the relationship between agricultural trade and economic growth of many countries. This section briefly discusses some previous theoretical and empirical studies based on the relationship between agricultural trade and economic growth developed and developing countries. There are a quite few studies which focused on the relationship between agricultural trade and economic growth. [Sarbapriya Ray (2011); Muhammad Zahir Faridi (2012); Shujaat Abbas (2012; Harikumar (2014); Hyunsoo Kang (2015); Muhammd Abrar UL Haq and Universiti Utara Malayasia (2015); Nahana Verter and Vera Becvarva (2016); Mohsen Mehrara and Javad Baghbanpour (2016); Cynthia Johannes P.S. Sheefenil (2017); Dilshad Ahmad and Jamil Ahmad (2018); Muhammad Bello Abubakar and et al. (2018); W. Khan, S.A. Ansari (2018)]. The above analysis clearly shows that there are many studies in India and abroad regarding a particular aspect of the agricultural trade. India is in the process of completing more than two decades of economic reforms. A number of studies have been undertaken in recent times to study the impact of agricultural trade by taking minimum economic variables, and they have used very simple econometrics methodology by annual time series data. Agricultural trade, so that corrective measures can be taken. To this end the researcher has undertaken this vibrant issue for research. The survey points out the fact that the causal relationship between agricultural trade and economic growth in India are limited in number. This explains the need for the present study. More specifically, the objective of the study is to investigate the causal relationship between agricultural trade and economic growth in India.

\section{DATA AND METHODOLOGY}

The main focus of the study was to investigate the relationship between agricultural exports and economic growth in India.

- The Gross Domestic Product (GDP) is widely used in the literature as a proxy for economic growth for a country. GDP signifies the economy's output per year.

- The agricultural exports play a major role towards the expansion of the total exports and economic growth of the country after reforms period.

Therefore, this study examines the causal relationship between trade and economic growth in India. The annual time series data on GDP, agricultural exports and non- agricultural exports from 1990-91 to 201617 had been used. All the data were measured at 2004-05 constant prices and transformed into natural logarithms. All the annual time series data were extracted from published sources such as Handbook of statistics on Indian Economy by Reserve Bank of India, Ministry of Agricultural, Government of India, Ministry of Agriculture and Farmers Welfare, Government of India, Ministry of Commerce and Industry, Government of India.

\section{RESULTS AND DISCUSSION}

\section{Unit Root Test}

The first step of the estimation process is to check the time series properties of the data. Most of the economic variables are non-stationary in their level form. These non-stationary time series may result in spurious regressions. To avoid problem of spurious results, it is necessary to investigate the order of the integration of the variables included in the study. Therefore, first, this study analyses the time series properties by using unit root test such as, Augmented Dicky-Fuller (ADF) test.

Table 1 explains from the results conducted by the ADF test that these three variables are in nonstationary level (intercept and trend and intercept), since the ADF test statistics is lower than test critical values and also the probability values are insignificant, which are more than 5 per cent level. Therefore, this study accepts the null hypothesis $\left(\mathrm{H}_{0}\right)$ that there is unit root at level that has been accepted for all the variables. In order to make these series stationary, this study has differenced to order one: the results also presented in the same 
Table 1: Results of Unit Root Applying ADF Test

\begin{tabular}{ccccc}
\hline \multirow{2}{*}{ Variable } & \multicolumn{2}{c}{ Intercept } & \multicolumn{2}{c}{ Trend and Intercept } \\
\cline { 2 - 5 } & Level & First Difference & Level & First Difference \\
\hline LnGDP & 2.0352 & $-4.3575^{*}$ & -1.6602 & $-4.1973^{* *}$ \\
LnAgriExport & -0.1679 & $-3.7625^{*}$ & -2.5374 & $-3.6699^{* *}$ \\
LnNon Agri Exp & -1.7495 & $-4.6138^{*}$ & -0.6110 & $-4.8810^{*}$ \\
\hline
\end{tabular}

Note: ${ }^{*}$ and ${ }^{* *}$ denote significance at the 1 and 5 per cent level.

Table 2: Result of Johansen Co-integration Test

\begin{tabular}{cccccccc}
\hline $\begin{array}{c}\text { Null } \\
\text { Hypothesis }\end{array}$ & $\begin{array}{c}\text { Eigen } \\
\text { Value }\end{array}$ & $\begin{array}{c}\text { Trace } \\
\text { Statistics }\end{array}$ & $\begin{array}{c}\text { 5 per cent } \\
\text { critical Value }\end{array}$ & P-Value & $\begin{array}{c}\text { Max-Eigen } \\
\text { Statistics }\end{array}$ & $\begin{array}{c}\text { 5 per cent } \\
\text { critical Value }\end{array}$ & P-Value \\
\hline $\mathrm{r}=0$ & 0.7157 & 50.0019 & 29.7970 & $0.0001^{*}$ & 30.1906 & 21.1316 & $0.0020^{* *}$ \\
$\mathrm{r} \leq 1$ & 0.5494 & 19.8112 & 15.4947 & $0.0105^{* *}$ & 19.1331 & 14.2646 & $0.0078^{* *}$ \\
$\mathrm{r} \leq 2$ & 0.0278 & 0.6780 & 3.8414 & 0.4102 & 0.6780 & 3.8414 & 0.4102 \\
\hline
\end{tabular}

Note: * and ${ }^{* *}$ denote significance at the 1 and 5 per cent level.

Table 1. After taking first differences I (1) of these, three variables are stationary. That is, the ADF test statistics is greater than critical values at one per cent and five per cent level of significance. Here, this study rejects the null hypothesis $\left(\mathrm{H}_{0}\right)$. This means, the results confirm that all the variables become stationary when estimated at first difference using intercept and trend and intercept.

\section{Johansen Co-integration Test}

After completion of unit root testing in the time series, assuming that all our time series are integrated of the same order, this study conducts Johansen co-integration test to find out the long run equilibrium relationship between the variables. The Johansen process is a maximum likelihood method that determines the number of co-integrating vectors in a non-stationary time series Vector Auto Regression with restrictions imposed, known as an Error Correction Model (ECM).

The present analysis finds that variables in the estimation are integrated of order one, so this study concludes that there is a possibility of existence of a co-integration among the variables. Now, the Johansen co-integration test is performed to investigate any long-run equilibrium relationships among the variables of GDP, agricultural export and non-agricultural export. The results of Johansen cointegration rank test is summarized in Table 2. The Trace test and Max-Eigen test have been performed which indicates that the trace statistics is greater than critical value $(50.0019>29.7970$ and 19.8112 $>15.4947)$ at one per cent and five per cent level of significance and the Max-Eigen Statistic test is also greater than critical value (30.1906 $>21.1316$ and $19.1331>14.2646$ ) at one per cent and five per cent level of significance. These results explain the presence of one co-integration vector at one per cent level of significance. Respectively, that is, the null hypothesis of no co-integration is rejected for rank of zero. This means that there exists a long-run relationship among the three variables.

\section{Error Correction Model}

This must be noted that in the presence of one or more co-integrating vectors, the simple VAR method does not produce the desired results unless an error correction term is included in the model. Thus, a Vector Error Correction model has been applied in this study. Johansen co-integration test has found that there exists one co-integration relationship among these three variables. Further, this study has applied Error Correction Model (ECM) to estimate the long-run relationships among the variables and the outcomes are presented in Table 3. The appropriate lag length (lag -2) of the variable has been selected through the Akaike Information Criterion (AIC). The model explains that where GDP $(Y)$ is the dependent variable and co-integrating equation, then agricultural exports and its lagged values, non-agricultural exports and its lagged values are the independent variables. The 
Table 3: Error Correction Model

\begin{tabular}{|c|c|c|c|c|c|c|c|}
\hline \multicolumn{2}{|c|}{ Error Correction } & \multicolumn{2}{|c|}{ Coefficient } & \multicolumn{2}{|c|}{ Std. Error } & t-Statistic & Prob. \\
\hline \multicolumn{2}{|c|}{$\mathrm{ECM}_{\mathrm{t}-1}$} & \multicolumn{2}{|c|}{-0.4132} & \multicolumn{2}{|c|}{0.0668} & -6.1803 & $0.0000^{*}$ \\
\hline $\mathrm{R}^{2}$ & 0.7608 & Adj. $R^{2}$ & 0.6562 & F- Test & 2.2735 & D-W stat. & 2.1976 \\
\hline
\end{tabular}

Note: * denote significance at the 1 per cent level.

Table 4: Results of VEC Granger Causality/Block Exogeneity Wald Tests

\begin{tabular}{|c|c|c|c|c|}
\hline Null Hypothesis & F- Test & df & P-Value & Direction \\
\hline Agricultural Export does not granger cause GDP & 15.8383 & 2,16 & $0.0002^{*}$ & \multirow{2}{*}{$\begin{array}{l}\text { Uni-directional } \\
\text { causality }\end{array}$} \\
\hline GDP does not granger cause Agricultural Export & 1.3540 & 2,16 & 0.2862 & \\
\hline GDP does not granger cause Non- Agricultural Export & 2.4013 & 2,16 & 0.1225 & $\begin{array}{l}\text { Uni-directional } \\
\text { causality }\end{array}$ \\
\hline $\begin{array}{c}\text { Agricultural Export does not granger cause Non- } \\
\text { Agricultural Export }\end{array}$ & 0.0260 & 2,16 & 0.1225 & \multirow{2}{*}{ No causality } \\
\hline $\begin{array}{l}\text { Non-Agricultural Export does not granger cause } \\
\text { Agricultural Export }\end{array}$ & 0.5023 & 2,16 & 0.2524 & \\
\hline
\end{tabular}

Note: ${ }^{*}$ and ${ }^{* *}$ denote significance at the 1and 5 per cent level.

estimations of the coefficient of error correction term $\left(\mathrm{ECM}_{\mathrm{t}-1}\right)$ is associated with the restoring force toward equilibrium which is negative $(-0.4132)$ and statistically significant at one per cent level. The error correction term $\left(\mathrm{ECM}_{\mathrm{t}-1}\right)$ shows 41.32 per cent of the deviations in the long-term equilibrium that can be adjusted within a year period. Therefore, the error correction mechanism, that is to say, catch can tend towards the long run relationship, has been validated. The negative and significant value of the coefficient of error term suggests that the variables are converging to equilibrium value and the change in agricultural exports and non-agricultural exports are directly affecting real GDP in India.

\section{VEC Granger Causality/Block Exogeneity Wald Tests}

Firstly, this study finds the short-run granger causality between agriculture exports and GDP in India. The Granger causality test result shows that $F$-statistic value is 15.8383 and probability value is 0.0002 , which means that the null hypothesis of agriculture exports does not granger cause GDP, which is rejected at one per cent level of significance. Therefore, it can be concluded that the short-run agriculture exports granger causes GDP in India. On the other hand, The GDP does not granger cause agriculture exports because probability value is insignificant.
Secondly, Granger causality test was used to verify the direction of short-run causality between nonagricultural exports and GDP in India. The Granger causality test result displays that the direction of causality is from non-agricultural exports to GDP since the estimated $F$ - statistic value is 15.5419 and probability value is 0.0148 . This means the null hypothesis of export does not granger cause GDP, which is rejected at five per cent level of significance. This means, non-agricultural exports granger causes GDP in India. On the other hand, The GDP does not granger cause non-agriculture export because probability value is insignificant. Lastly, this study evaluates the short-run granger causality between agricultural exports and non-agricultural exports in India. There is no granger causality between agricultural exports and non-agricultural exports in India because probability values are insignificant. Therefore, the short-run granger found that there is uni-directional causality between agriculture exports, non-agriculture exports to GDP in India.

\section{CONCLUSION}

This study estimated the relationship between agricultural trade and economic growth in India employing Vector Error correction model for the period from 1990-91 - 2016-17. This study has used three variables such as, GDP, agricultural export and non-agricultural exports. The empirical analysis 
found that all variables used in this study are first difference stationary. Based on the time series properties of the variables Johansen Co-integration test was used to find a long-run equilibrium relationship among the variables. Furthermore, the Error Correction Mechanism, that is to say catch can tend towards the long run relationship. The coefficient of error term suggests that the variables are converging to equilibrium value and the change in agricultural export and non-agricultural are directly affecting the real GDP in India. Furthermore, this study found that there is short-run unidirectional causality between agriculture exports, non-agriculture exports to GDP in India. The main finding of this study is that the agricultural export and non-agricultural export are important variables to stimulate economic growth in India. The study recommends an increase effort to be directed towards policies that will expand the volume of a country's agricultural productivity and trade for the economy. Agriculture must have significant importance, increasing productivity through priority policy measures of adequate provision of inputs, infusion of innovative mechanization and minimization of market imperfection. Agriculture exports affect economic growth government must have priority measures regarding to agriculture crops, livestock and forestry. Adequate provision of quality inputs, infusion of advance mechanization, availability of credit, farming training campaign to improving efficiency by agriculture extension department and improving market mechanism for proper support price of agriculture commodities are prerequisite measures for agriculture growth. Agriculture productivity will meet the local demand of country and its export will source of foreign exchange earnings. Agro based industries must develop in agriculture sector for convergence of value added commodities rather than raw material for agriculture exports.

\section{REFERENCES}

Anthony Siaw et al. 2018. Agricultural Exports and Economic Growth: A Disaggregated Analysis for Ghana. Theoretical Economics Letters, 8: 2251-2270.

Ashoka, N. et al. 2016. Econometric analysis of wholesale coffee prices and exports from India. Economic Affairs, 61(3): 437-445.

Cynthia Simasiku and Johannes P.S. Sheefeni. 2017. Agricultural Exports and Economic Growth in Namibia. European Journal of Basic and Applied Sciences, 4(1): 41-50.
Damodar Gujarati. 2011. Econometrics By Example. Palgrave Macmillan. New York.

Dickey, D.A. and Fuller, W.A. 1979. Distribution of the estimators for autoregressive time series with series with a unit root. Journal of the American Statistical Association, 74(366): 427-431.

Dilshad Ahmad and Jamil Ahmad. 2018. An empirical analysis of agricultural export on economic growth: A case study of Pakistan. International Journal of Advanced and Applied Sciences, 5(2): 25-32.

Fakhre Alam and Godwin Myovella. 2017. Causality between Agricultural Exports and GDP and its Implications for Tanzanian Economy. IOSR Journal of Economics and Finance (IOSR-JEF), 8(I): 36-49.

Granger, C.W.J. 1988. Some Recent Development in a Concept of Causality. Journal of Econometric, 39: 199-211.

Guledgudda, S.S. et al. 2014. Export performance of Indian cashewnut - An analysis. Economic Affairs, 59(4): 669-674.

Handbook of Statistics on Indian Economy by Reserve Bank of India.

Harikumar. 2014. Changing Phases of the India's International Trade before and after Liberalization Period. International Journal of Application or Innovation in Engineering $\mathcal{E}$ Management, 3(3): 72-76.

Hyunsoo Kang. 2015. Agricultural exports and economic growth: Empirical evidence from the major rice exporting countries. Agric. Econ-Czech, 61(2): 81-87.

Johansen, S. 1988. Statistical analysis of cointegrating vector. Journal of Econometric Dynamics and Control, 12: 231-254.

Karthick, V. et al. 2015. Growth and Export Performance of Ginger in India- An Economic Analysis. Economic Affairs, 60(2): 207-214

Kerobim Lakra et al. 2014. Comparative Advantage in Export of Major Agricultural Commodities in India: A Postreforms Analysis. Economic Affairs, 59(2): 107-116.

Khan, W. and Ansari, S.A. 2018. Does Agriculture Matter for Economic Growth of Uttar Pradesh (India)?. Economy of Region, 14(3): 1029-1037.

Matandare, M.A. 2017. Agriculture Exports and Economic Growth in Zimbabwe. International Journal of Social Science and Economic Research, 2(12): 5503-5513.

Ministry of Agricultural, Government of India.

Ministry of Agriculture and Farmers Welfare, Government of India.

Ministry of Commerce and Industry, Government of India.

Mohsen Mehrara and Javad Baghbanpour. 2016. The Contribution of Industry and Agriculture Exports to Economic Growth: The Case of Developing Countries. World Scientific News, 46: 100-111.

Muhammad Bello Abubakar and et al. 2018. Agricultural Export Performance and Economic Growth in Nigeria: Error Correction Modelling Approach. Journal of Emerging Trends in Economics and Management Sciences, 9(1): 45-51. 
Muhammad Zahir Faridi 2012. Contribution of Agricultural Exports to Economic Growth in Pakistan. Pak. J. Commer. Soc. Sci., 6(1): 133-146.

Muhammd Abrar UL Haq and Universiti Utara Malayasia 2015. Agricultural Export and Economic Growth: A Case Study of Pakistan. Public Policy and Administration Research, 5(8): 88-96.

Nahana Verter and Vera Becvarva 2018. The Impact of Agricultural Exports on Economic Growth in Nigeria. Acta Universitatis Agriculturae Et Silviculturae Mendelianae Brunensis, 14(81): 691-700.

Neelam Rani and Neelam Dhanda 2011. Foreign Direct Investment and Foreign Trade: Empirical Evidence from India. International Journal of Research in Financial and Marketing, 1(3): 67-89.
Sarbapriya Ray. 2011. Exploring Cointegration and Causality between Foreign Trade and Economic Growth: Econometric Evidence from India. International Journal of Contemporary Business Studies, 2(10): 53-69.

Shujaat Abbas. 2012. Causality between Exports and Economic Growth: Investing Suitable Trade Policy for Pakistan. Eurasian Journal of Business and Economics, 5(10): 91-98.

Syed Wahid Ali Shah et al. 2015. Agricultural Export and Economic Growth: A Case Study of Pakistan. Public Policy and Administration Research, 5(8): 88-96.

Udeshna Talukdar and Hazarika, C. 2017. Production and Export of Value Added tea in India and its Global Competitiveness. Economic Affairs, 62(4): 705-710. 